\title{
A Critical Review on the Ideological and Symbolic Role of the Arabic Language in National Identity in the Arab World
}

\author{
Ali Alsohaibani \\ $\mathrm{PhD}$ candidate at University of East Anglia, School of Politics \\ Philosophy and language and communication studies, Norwich, NR5 9JQ, the UK \\ a.alsohaibani@uea.ac.uk
}

\begin{abstract}
This study aims at examining the symbolic role of Arabic, particularly Standard Arabic, other than its instrumental and communicative role, on Arabs national identities. The symbolic function of the language has been chosen as it plays an important role in forming the beliefs and ideologies of the people towards their identities generally, and their national (or collective) identity in particular, which in turn influences the practices and policies of the language. Moreover, it has always been considered a very significant issue in the identification of national identity, whether in its role as a marker for national identity or an aspect of other important ingredients. The study can confirm how the Arabic language is ideologically important to Arabs and how it has been used as an instrument for resisting the cultural, and sometimes political, challenges to identities from others. It can be said that the symbolic function of Arabic makes it one of the languages that are infused with ideology.
\end{abstract}

Keywords : National identity, language ideology, language identity, Arabic identity.

\section{INTRODUCTION}

Language has always been considered a very significant issue in the identification of national identity, whether in its role as a marker for national identity or an aspectof other important ingredients. Arabic language, as one of the most spoken languages in the world, is seen by Arabs as a powerful symbolthat reflects their national identity and their sense of belonging to past glory, a combatant present and a bright future. This symbolic role of Arabic, particularly Standard Arabic, other than its instrumental and communicative role, will be discussed in the present research. The symbolic function of the language has been chosen because it plays animportant role in forming the beliefs and ideologies of the people towards their identities generally, and their national (or collective) identity in particular, which in turn influences the practices and policies of the language.

This will start byreviewing some conceptual meanings of national identity generally and the divergent perspectives onthe role that language plays in the identification of nations. Then, the ideological and symbolic role of Arabic will be discussed, referring to historical and present issues that reflect this role of Arabic in Arabs' national identity. Finally, some light will be shed on the relationship between Arabic and Islam and how that contributesto national identity.

\section{WHAT IS MEANT BY NATIONAL IDENTITY?}

National identity is anideological concept that cannot be easily identified. Several disciplines have ideological relations in defining this concept, such as politics, sociology, history, anthropology, sociolinguistics, etc. The complexity of defining national identity comes from its formation and because it is a phenomenal sense that is formed over a very long period of time. Another problematic issue is the similarity and overlap between ethnic identity and national identity, which might be similar butsometimes are not. For example, Oakes (2001) argues that any definition of ethnicity should include some characteristics thatindividuals must have in common, such as religion, culture, origin, values and sense of belonging. Likewise, Krejci and Velimsky (1981) describesome features that contribute to identifying a nation. These features are: territory, state, language, culture and history. If these features exist in a community, they add a sixth feature, which is a national identity. Thus, the perceived similarity between the two definitions of ethnic identity and national identity can be noticed. 
In the literature, there are two orientations by which nations are recognised. One is based on the civic recognition of anation and the other is on the ethnic recognition (Smith, 1991). The former is usually associated with nations such as America, Australia, the Netherlands, France, etc. The latter is often associated with nations such as Germany, Sweden and some Eastern European and Asian nations. The Arab world as one nation can be considered in the secondone (this will be discussed later). A civic nation is seen as a "community of laws and institutions with a single political will" (ibid: 10). On the other hand, anethnic nation is anation thatoften has a common descent, traditions and values, which might be grounded historically and mythically (Suleiman, 2003).

To some scholars, ethnic national identity is synonymous withcultural national identity. Cultural national identity may cross the borders of specific countries, disregarding the political boundaries, to form a cultural national identity. In this respect, the Arab national identity can be deemed as a cultural national identity that exists in several states thatare not politically unified ${ }^{1}$. One of the motivations behind the emergence of the cultural national identity on the surface is the feeling of external challenges and threats tothe existing traditional beliefs and values of the community, which make people, particularly e lites, react and defend their culture (Gellner, 1983). Actually, this is exactly what happened with the Arab cultural national identity and the challenges tothe Arabic language, as will be explained later.

\section{LANGUAGE AND NATIONAL IDENTITY}

The relationship between language and national identity has always been a very controversial issue in terms of its importance and role in formulating the collective identity of a nation. Some scholars consider it to beone of the major components, if not the most major, that construct the national identity of any community. To others, language is one factor among other more important factors thatparticipate in defining the national identity of any nation. It can be claimed that the perspective that the essentiality of language in constructing anation has emerged before others that do not consider language very important in formulating nations' identities. The ideological link between language and national identity is often associated with the German Romanticism movement and particularly with the $19^{\text {th }}$ century German philosopher and thinker Fichte (Anderson, 1983). This perceived relationship between language and national identity was reflected in German philosophicaldiscourse, which contained calls for the purification of the German language from borrowed words that might affect the pure German language and consequently contaminate the German national identity (Hobsbawm, 1990). Hobsbawm (ibid: 102-3) demonstrates this strong relationship between language and national identity by referring to the German and Italian languages as "...more even than the vehicle of a distinguished literature and universal intellectual expression. It was the only thing that made them Germans and Italians, and consequently carried a far heavier charge of national identity...." It can be said that this orientation of thought has been influenced by the ethnic definition of national identity. That is, language is amirror that reflects the history of specific people and it is avehicle thatcarries their past, with its myths and events, to the present.

There have been many national movements thathave been, directly or indirectly, influenced by the ideology of German Romanticism and its perception of the essential role of language in constructingnational identity. For instance, the Irish language became an important issue in Irish nationalist movement discourse at the end of the $19^{\text {th }}$ century, after the establishment ofthe Gaelic League (Suleiman, 2003). The same is the case with other languages in Europe, such as Finnish in Finland and Catalan in some parts of Spain. The language issue has become a crucial marker in the discourse of nationalist movements in Finland and Catalonia (ibid.).

Although one of the significant roles of language in formulating national identity can be through communicative and social functions, such as the acquisition and learning of values, traditions and the exchange of experiences and information, the more significant role is the symbolic one. This symbolic function of language is motivated by considering language as "the link with the glorious past" of the nation (Fishman, 1972). This could be more obvious with nations whose greatness and glory havebecome part of the past. In this sense, language means history, science, literature, religion, etc. It would be the foundation of the bright future of anation. Fishman (ibid.) observes that history and language arethe first two needs of a nation. He considers them two sides of the same coin. Moreover, language is abridge for bringingpresent achievements to futuregenerations. In comparison to other

\footnotetext{
${ }^{1}$ There are, of course, some differences between Arabs in different states, but the discussion here is about the "common feelings" of Arabs generally.
} 
collective symbols of identity, language is the most primary symbol. Sometimes, it is more potent than religion, territory or political state. For example, religion might be shared by many nations thatare not unified. Also, religion has been seen negatively by some peoplein recent times.

In terms of territory, there are some groups or communities who live in the same territory and in the same political state but do not feel they havethe same national identity. A typical example of this is the Kurds in Iraq. On the other hand, the Arabic language has played the most important role in somewhat unifying the Arab population across the many territories and political borders from the Arabian Gulf (or the Persian Gulf) to the Atlantic Ocean. However, it can be argued that there are some nations who share the same language with other nations and do not enjoy one national identity, or nations (or groups) who live in the same land and political state speaking different languages and maintaining one national identity. For the former, it can be claimed that some of these nations do not have a long history of association between language and the land where they live and, as was demonstrated, ahistorical and linguistic link is crucial for asense of national identity. For instance, nations in South America who speak Spanish do not have one national identity with the people in Spain because the Spanish language in Spain has a long historical dimension, while in South American countries the historical dimension of Spanish is limited or, sometimes, the language was enforced over a specific period of time (the language of the coloniser). As for nations who live in the same political state and have one national identity, itcan be argued that the collective sense of a unified nation would be insubstantial comparedto that of unified nations with one national language. In Canada, for instance, the Quebec national identity (which is mainly attributed to the French language) is more important to some people than the Canadian national identity (Jouglard, 2008). Similarly, the Catalonian national identity in Spain is considered to be the prevailing national identity in Catalonia. The feeling of a faint national identity caused by different languages in one political state was reflected by the great Swiss historian Karl Dandliker, who declared that "the Swiss people did not enjoy the advantage of their neighbours: being a nation in the true and literal sense of the word, that is to say, be ing an entity uniform in terms of linguistic and ethnic composition" (as cited in Kaufmann and Zimmer, 1998: 497-98). Of course, there are some countries (nations) thatinclude many official languages and enjoy a certain type of national identity, but the question is: to what degree is this feeling of belonging considerable comparedto the regional or territorial national identity, especially if it has been attached toone language?How can they substantially feel unified and practice this unity if they do not share the same events, songs, poems, daily experiences, etc.?In other words, theylivein relatively different cultures.

Moving to another practical and non-symbolic factor thatindicates the relationship between language in its functional role and national identity, Anderson (1983) argues that 'print-capitalism' or, in other words, the printed press and book publishing in the vernacular languages of Europe, played a salient role in the emergence of nationalist movements in Europe. Generally, he claims that the printing revolution made nations imagine themselves to be antique (the historical dimension). The role of the printed press can also be noticed in the Arab world when French colonisers brought the first printing machine to Egypt and published the first newspaper in the Arabic language atthe beginning of the $19^{\text {th }}$ century. Although the purpose of this newspaper was not to agitate nationalism in the Arab world but to divide it from the Ottoman Empire, it somehow contributed to formulating a sense of national identity among Egyptians and Arabs generally (Suleiman, 2003).

This conjuncture and the harbingers of Arabs' nationalismand therelationship with the Arabic language will be furtherdiscussed, but before that some light should be shed on the characteristics of Arabic and the nature of Arabs' identity. Mentioning such a background willgive indications ofsome of the beliefs that Arabs have towards their languagethatmight have contributedto ideological attitudes concerning Arabic and national identity.

\section{The Arabic language and Ideological Characteristics}

The Arabic language is the most spoken Semitic language among other Semitic languages such as Hebrew, Aramaic, Amharic, etc. Semitic languages have a long history goingback thousands of years. According to some studies, all of these languages originated in what is today called the Arab world ${ }^{2}$ (De Young, 1999). Although Arabic, before the emergence of Islam, was spoken by a minority of

\footnotetext{
${ }^{2}$ So me scholars do not agree with this view and advocate the view that they originated in East Africa in Somalia (which is a member of the Arab League) or Ethiopia (De Young, 1999).
} 
people in the Arabian Peninsula, Arabic today is the official language of 24 countries stretching from the Arabian Gulf inthe east to the Atlantic Ocean inthe west, and from the Mediterranean Sea in the north to the Horn of Africa and the Arabian Sea in the south, with a population of around 325 million people. With the exclusion of some minorities, Arabic, whether standard or dialectical, is the spoken language in all these countries and for some minor populations in the countries bordering the Arab world, such as Turkey, Israel, Chad, Senegal, etc. (UNESCO, n.d.).

The Arabic language is often connected with the Quran and the prophet Muhammad's Hadiths (sayings and deeds). It isalso linked to scientific developments in the Iberian Peninsula during Islamic rule. For some Arabic linguists, Arabic has many features thatmake it distinctive from other languages. For example, it is called the language of the $d a d$, the phoneme $/ d /$, which is only found in Arabic $^{3}$. Suleiman (2003) argues that referring to Arabic in such a way is not just to signal it but also to define the group identity when identifying Arabs as the speakers of $/ d /$. Another example that reflects the beliefs of some Arab linguists towards Arabic is the distinctive nature of it as an original derivational language (ibid.). That is, the roots of many words in Arabic are based on acoustic and mental images. This indicates that the relationship between the 'signified' and the 'signifier' is not conventional or arbitrary,as Saussure suggests,but 'natural'. Al-Arsuzi (1900-68) (as cited in Suleiman, 2003), who is a well-known Arab linguist, argues that the sources of most Arabic words are natural. One example of this is the imitation of the sounds of nature or the sounds of the mouth for expressing certainfeelings and emotions, which can be regarded as an expanded usage of onomatopoeia. These discussed features of Arabic are some examples of linguistic characterisation that may influence some Arabic native speakers' ideology of language. To conclude, it is worth citing howHourani (1962: 1) describes Arabs:

More conscious of their language than any people in the world, seeing it not only as the greatest of their arts but also as their common good, most Arabs if asked to define what they meant by the 'Arab nation', would begin saying that it included all those who spoke the Arabic language.

\section{WHO IS IDENTIFIED AS AN ARAB?}

Answering this question is essential because of the relationship between defining identity in general and definingnational identity. Historically, the term 'Arabs' was used to refer to the tribes who lived in the Arabian Peninsula and its borders to the north for hundreds of years before Islam. After the emergence of Islam and the establishment of the Islamic Empire, some Arabs moved to live in the conquered territories and tooktheir religion and language with them, which became the language and religion of the inhabitants in the newly conquered regions (De Young, 1999). As those inhabitants became Muslims and acquired the language of the ir new religion while co-living with the conquerors, their identity as new Arabs started to form. Examples of this are some Copts in Egypt, some Berbers in North Africa, some Africans in the Horn of Africa, etc. On the other hand, many Muslims from different places in the world, e.g. from Europe, Africa, Central Asia, South and East Asia, etc., moved to live in the 'holy land' of Islam, became natives in this region and have been considered to be Arabs. Thus, in a very subjective way and similar to what Marr (1998, as cited in Sule iman, 2003: 22) says about Scottish national identity: "fundamentally, Scotland is a nation because it believes itself to be one", some Arab scholars and theorists deem everyone for whom Arabic is his/her mother tongue and who considers himself/herself to be an Arab is an Arab. Al-Husri (1956), a great Arab ideologist, defines anArab as anyone who belongs to an Arab country and speaks Arabic,regardless of his/her religion, official citizenship, ancestry and the roots of their families.

\section{The Arabic Language and National IDENTITY}

As discussed earlier, language has always been deemed a very important issue in the identification of national and cultural identity, whether for its role as a marker for national identity or as one ingredient among other ingredients. With respect to the Arabic language, it seems that ithas been considered a marker of the Arabs' national identity. Besides what has been mentioned about the definition of an Arab and the essentiality of Arabic in that definition, this can be demonstrated by referring to some views and insights that appeared in a specific period of time andfilled the social, political and cultural discourses at that stage.

\footnotetext{
${ }^{3}$ The is sue is not whether this is true or not but how they perceive their language.
} 
As Gellner (1983) suggests, nationalist movements are often defensive and reactive movements lead by educated elites to protect the cultural and social fabric. In relation to this,Arab nationalism and the discourse of one Arab national identity as national movements emerged in a defensive and reactive historical context,and the Arabic language was a very important motivation thatcontributed tothis movement. The historical context in which Arab nationalism became apparent and developed was the end of the $19^{\text {th }}$ century and the beginning of the $20^{\text {th }}$ century, when the Arab world was under the rule of the Ottoman Empire in some areas and the French Empire in others. It is not an exaggeration that the challenge on Arabic language and, consequently, national identity was one of the most potent factors to spark the interest innational identity in the Arabworld.

A vast area of the Arab lands had been ruled by the Ottoman Empire for almost seven centuries, which tookonan Islamic framework for ruling. Arabs and Ottomans (Turks) co-habitedthese areas with some degree of harmony. At that time, Arabic was an official and national language in the Arab world. However, this harmony turned into disagreement and conflict when the Ottoman Empire started to waive the Islamic framework of its rule and adopt secularism, associating it with glorifying the Turkish language and Turkish identity at the end of the $19^{\text {th }}$ century. This national movement made them enforce the Turkish language in some Arab territories, particularly in the Levant region (Syria, Lebanon, Palestine and Jordan) and especially in the educational domain. This irritated Arabs, ideologists and scholars, who considered the attack on Arabic as an attack on the Arab national identity and the cultural values attached toit. An example of the orientation that was adapted by the new Turkish nationalists against the Arabic language is the following extract from a Turkish writer:

The Arabs do not stop prattling in the ir language and they are total ignoramuses in Turkish, as if they were not under Turkish rule. The government is obligated in such a case to force them to forget their language and learn the language of the nation that is ruling them (Tauber, 1993:56-7, as cited in Suleiman, 2003: 85).

Such an attack on the Arabic language urged Arabs, Muslims and Christians (some of whom were leaders of Arab nationalism) to awakenasense of national identity in the public.

Meanwhile, Arab thinkers and some religious scholars began to write about the concept of national identity or what can be called pan-Arabism, which is an extension of national identity. It can be said that these movements of resistance by Arab thinkers and elites were more anchored in cultural national identity than political identity. Arabic played a significant role in this :symbolically as the face of the culture and functionally as press publishing was booming (Al-Husri, 1956). Al-Husri (ibid.) mentions that when there where negotiations and encounters between Arab elites and Turkish governors, the most important issue that was discussed was the Arabic language and its significance in the Arabs' consciousness. He also points out that when the Ottoman rule began to recede, he became responsible forthe education system in Syria. The first thing he did was to change the curriculums into Arabic and to teach Arabic intensively in schools.

In the same historical period and in another part of the Arab world, the same attack on national and cultural identity with the language weapon was occurring in Algeria as a result of the French colonisation. The French language was enforced as the official language of the country. The French authorities realised the centrality of Arabic in religion and social relations and the role of it in the unity of the society, although there were some minorities such as Berbers who lookedatArabic positively (Bassiouney, 2009). So, similar to what the Turks did in Syria, the French authorities imposed the French language on the educational system, banned the use of Arabic in schools and closed many religious schools. These practices by the French against the Arabic language and cultural values created a reaction among Arabs, moving them to establish many national movements that considered the Arabic language and religion to be their anchors (Holt, 1994). Actually, this national identity that was based on Islam and Arabic was expressed through statementssuch as "Islam is our religion, Arabic our language and Algeria our fatherland", which became national slogans releasedby the nationalist leaders (Bassiouney, 2009: 215). Although these national movements took on a political nature, it can be claimed that the cultural nature, especially in relation to language, was the most effective motivation to unify the nation.

On the political level, and after the successive independences of Arab countries, several Arab countries included the Arabic language in their constitutions as the official and national language. 
Furthermore, most of them added the word 'Arabian' to the official names of the countries. Gamal Abdel Nasser, the Egyptian president and godfather of pan-Arab nationalism, addressed the United Nations in 1960, saying: "We announce that we believe in a single Arab nation. The Arab was always united linguistically. And linguistic unity is unity of thought" (Dajani, 1973, as cited in Bassiouney, 2009: 242).

On the scientific and cultural level, several language academies were established to protect and preserve the Arabic language and to work on the development of Arabic to meet the needs of the know ledge revolution in all domains through 'Arabicisation'. There have been the Arab Academy of Damascus, the Arabic Language Academy in Cairo, the Iraqi Academy, the Arabic Language Academy in Jordan and the Arabic Language Academy in Libya and Algeria (Spolsky, 2004). In the same context, the cultural scene was full of publications, press essays, lectures and forums on the same issue:the defence of the Arabic language (Bassiouney, 2009; Suleiman, 2004).

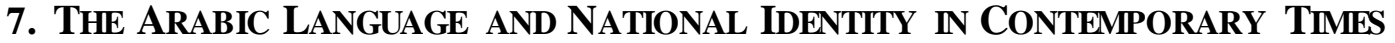

A more modern and complex conflictual sphere that reflects the significant relationship between language and national identity is the linguistic conflict between Israelis and Palestinians. First and foremost, it is claimed that the Hebrew language and the call to revive it as part ofJewish identity and the attempts to make it spoken by Jewish communities in the diaspora gave the Jews a sense of national identity many years before the State of Israel was established (Al-Alaiyli, 1996).

Referring to the situation on the ground, both Arabs and Jews have negative attitudes towards using the other's language. They both consider the other's language as the language of the enemy. For instance, this has been clearly seen in the contestfor the names of some cities and places (Suleiman, 2004). Actually, thisnaming conflict can be somewhat seen inthe approach tonaming newborn babies:many Palestinians give the ir children names that mean 'struggler' and 'warrior' (Suleiman, 2011).

In a softerkind of language 'conflict', the currentlinguistic situation in the Gulf countries (Oman, Kuwait, Qatar, Bahrain, the United Arab Emirates and Saudi Arabia) is alarming. As a resultof the vast number of non-Arab workers in these countries, which sometimesreaches 65 per cent of the population (e.g. in the United Arab Emirates), this has led to the emergence of a negative linguistic phenomenon in the Arabic language, which is Pidgin Arabic. As a confrontation to this phenomenon, many writers and observers have called for laws and systems to protect the Arabic language, which in turn would preserve the national identity. In Saudi Arabia, educational and religious discourses are suffused with writings and lectures on attempts to tackle this challenge. In a more powerful and official way, the government in the United Arab Emirates has implemented a law to preventthe use ofPidgin Arabic in governmental offices (Bassiouney, 2009) ${ }^{4}$.

\section{ISLAM, ARABIC AND NATIONAL IDENTITY}

Religion, in general, has been one of the most potent powers that have influenced language change and language diffusion. For example, Latin, and the vernacular languages that developed from it, would have not spread throughout Europe if it had not been associated with Christianity in early times. Similarly, Islam carried the Arabic language with it as the religionspread from the Arabian Peninsula to territories in the east and west. Ferguson (1982, as cited in Spolsky, 2003) points out the relationship between language and religion, referring to writing systems. He claims that "whenever Western Christianity spread, it introduced a variety of Latin script for writing previously unwritten languages; similarly, whenever Islam spread it introduced Arabic script"5 (ibid:82). Thus, it can be assumed that without Islam, Arabic might be limitedly spoken in the Arabian Peninsula.

Another issue that reflects the relationship between language and religion is the viability and survival of some languages with sacred religious texts that were originally written inthose languages. For instance, Jews believe that the Torah was revealed in Hebrew and Muslims believe that the Quran was revealed in Arabic, which has granted the textsa kind of sacredness. In contrast, Christians are aware that the language of Jesus was not Latin, which might have relatively lessened the importance of Latin in Christianity and, possibly, this could be one of the reasons behind the transition from Latin to vernacular languages.

\footnotetext{
${ }^{4}$ Some Gulf countries were colonised by Western powers or ruled by the Ottomans in a limited way, so the rhetoric about language and national identity in these countries has come later.

${ }^{5}$ For example, Urdu, Persian and Kurdish all have Arabic scripts.
} 
By referring to the discussion about Arabic and national identity in some parts of the Arab world, it can be said that Arabic has been accepted and celebrated by Muslims, Arabs and non-Arabs because it is the language of the Quran. Bassiouney (2009) indicates that Berbers in the western Arab world consider Arabic to bea spiritual language and realise its necessity for them intheir daily religious practices. Actually, most Berbers speak Arabic. With respect to the language situation with the Turks when the Ottoman Empire had an Islamic nature and Arabic was deemed the language of religion, Arabs and Turks lived harmoniously. Arabs even called the Ottoman Empire 'caliphate', as an extension of the Islamic rule from the prophet's time. However, the situation differed when the Ottomans turned to secularism and started to enforce the Turkish language in the Arab world, which resulted in the emergence of the Arab national identity. Generally, Arabic is seen as a holy languageeven by non-Arabs, as Fishman argues (1996, as cited in Castleton, 2006).

As a symbolic function of Arabic in Muslims' identity, Arabic is the language of the Quran and is considered to beGod's word revealed in Arabic verbatim. Muslims believe that the Quran is untranslatable. Thisexplains why translators, especially Muslims, write: 'explanations' or 'interpretations' of the Quran when they translate the meanings of the Quran.

In a piece of research entitled "Arabic is the language of Muslims-that's how it was supposed to be", Jaspal and Coyle (2010) demonstrate the importance of Arabic to non-Arab Muslims and how it plays a significant role in their sense of a unified Islamic identity. The researchers cite several phrases and expressions said by some participants in the survey in praise of Arabic, such as "Arabic is holy [...] it's holy for Muslims", "Arabic is important for us because it's the prophet's language" (ibid: 23, 27). Similarly, Alshaer (2012) cites other phrases written by a Pakistani thinker and scholar thatrepresent the position of Arabic in the Muslim mentality and sense of identity. The Pakistani scholar says about Arabic:

The more you study its literature, the more you will be convinced that there is no other language more suited to express high ideals, to explain the most subtle aspects of Divine knowledge, and to impress the heart of man and mould it into submission to God (ibid:283).

As a functional and practical role that mirrors Arabic's presence in Muslim life, it is important to point out that the word Arab(ic) referring to the language has been mentioned several times in the context of praise. Furthermore, in regard todaily practices, the prayers that Muslims do five times every day must be in Arabic, which includes reciting some verses of the Quran.In addition, many invocations and rituals are practiced in Arabic.

\section{CONCLUSION}

Having discussed the ideological and symbolic role of Arabic in national identity, referring to some historical and recent practices, it can be noticed how the Arabic language is important to Arabs and how it has been used as an instrument for resisting the cultural, and sometimes political, challenges toidentities from others. It can be said that the symbolic function of Arabic makes it one of the languages that are infused with ideology. Thisis obvious from the definition of who an Arab is and the relationship between Arabic and nationalist movements, as well as the inseparable relationship between Arabic and Islam and how Arabic is looked at by Arab Muslims and Muslims generally.

It is worth mentioning that the focus of this research was onStandard Arabic rather than other dialectical formssince it has anideological and symbolic nature, whilethe dialects in the Arab world are only considered communicative 'languages'. It was the focus of the research because it has survived for centuries and is still homogeneous, while dialects are emergent and changeable. Finally, Standard Arabic was chosen because it is relatively understood by all Arabs and used by them as a means to overcomethe dialectical barriers, which is linguistically known as 'levelling'. ${ }^{6}$

\section{REFERENCES IN ARABIC}

Al-Alaiyli, A. (1996). Dustor al-arab al-qawmi. Beirut, Dar al-jadid.

Al-Husri, S. (1956). Ara' wa ahadith fi al-qawmiyya al-arabiyya. Beirut, Dar el-elm lilmalayeen.

\footnotetext{
${ }^{6}$ Holes (1995: 39) defines levelling as the 'elimination of very localised dialectical features in favour of more regionally general ones.'
} 


\section{REFERENCES}

Alshaer, A. (2012). Language as Culture: The Question of Arabic. In Sabry, T. (ed.), Arab Cultural Studies: Mapping the Field.London, I.B. Tauris and Co.

Anderson, B. (1983).Imagined Communities. London, Verso.

Bassiouney, R. (2009). Arabic Sociolinguistics. Edinburgh, Edinburgh University Press.

Castleton, B. (2006). Frequency and Function of Religiously-Based Expressions. In Morrow, J. (ed.), Arabic, Islam, and the Allah lexicon: How language shapes our conception of God. Lewiston, Edwin Mellen.

De Young, T. (1999).Arabic Language History.[online] Available at:<http://www.indiana.edu/ arabic/arabic_history.htm> [Accessed 11 April 2012].

Fishman, J. (1972). Language and Nationalism: Two integrated essays. Rowley, Newbury House Publishers.

Gellner, E. (1983). Nations and Nationalism. Oxford, Basil Blackwell.

Hobsbawm, E. (1990). Nations and Nationalism since 1780.Cambridge, Cambridge University Press.

Holes, C. (1995).Community, dialect, and urbanisation in the Arabic-speaking Middle East.Bulletin of the School of Oriental and African Studies.58 (2), 270-87.

Holt, M. (1994). Algeria: Language, Nation, and State. In Suleiman, Y. (ed.), Arabic Sociolinguistics: Issues and Perspectives. Richmond,Curzon.

Hourani, A. (1962). Arabic Thought in the Liberal Age, 1798-1939. Cambridge, Cambridge University Press.

Jaspal, R. and Coyle, A. (2010). "Arabic is the language of the Muslims-that's how it was supposed to be": Exploring language and religious identity through reflective accounts from young Britishborn South Asians. Mental Health, Religion and Culture. 13(1), 17-36.

Jouglard, R. (2008). National Identity Examined: A Study of the Quebec Nation. [online] Available at: <http://culturalshifts.com/archives/337> [Accessed 11 April 2012].

Kaufmann, E. and Zimmer, O. (1998). In Search of the Authentic Nation: Landscape and National Identity in Canada and Switzerland. Nations and Nationalism.4 (4), 483-510.

Krejci, J. and Velimsky, V. (1981).Ethnic and Political Nations in Europe. London, Croom Helm.

Oakes, L. (2001). Language and National Identity: Comparing France and Sweden. Amsterdam, John Benjamins B.V.

Smith, A. (1991). National Identity.Harmondsworth, Penguin Books.

Spolsky, B. (2003). Religion as a Site of Language Contact.Annual Review of Applied Linguistics.23, 81-94.

Spolsky, B. (2004). Language Policy. Cambridge, Cambridge University Press.

Suleiman, Y. (2003).The Arabic language and National Identity.Washington DC, George Town University Press.

Suleiman, Y. (2004).A War of Words: Language and Conflict in the Middle East. Cambridge, Cambridge University Press.

Suleiman, Y. (2011). Arabic, Self and Identity: A Study in Conflict and Displacement. Oxford, Oxford University Press.

UNESCO (n.d.).Arab States.[online] Available at: <http://www.unesco.org/new/en/unesco/world wide/arab-states/>[Accessed 11 April 2012]. 